\title{
PENGARUH ASIMILASI MODEL CUACA WEATHER RESEARCH FORECAST (WRF) DENGAN DATA RADIASI SATELIT TERHADAP ESTIMASI CURAH HUJAN (Studi Kasus Stasiun Meteorologi Pattimura-Ambon Tanggal 24-25 Juli 2013)
}

\author{
Habib Burrahman ${ }^{1}$, Andreas Kurniawan Silitonga ${ }^{2}$, Ilham Haris Batubara ${ }^{3}$, Ahmad \\ Fadlan $^{4}$
} 1,2,3 Program Studi Meteorologi, Sekolah Tinggi Meteorologi Klimatologi dan Geofisika,
Jl. Perhubungan I No.5 Pondok Betung, Pondok Aren, Tangerang Selatan

4 Sekolah Tinggi Meteorologi Klimatologi dan Geofisika, Jl. Perhubungan I No.5 Pondok Betung, Pondok Aren, Tangerang Selatan

Email : habibburrahman.97@gmail.com

\begin{abstract}
Numerical weather predictions are currently being developed to address the need for high resolution rainfall forecasting. However, numerical weather forecasts in Indonesia are still problematic in terms of the accuracy of numerical models. Several previous studies have shown that modeling accuracy is strongly influenced by errors in the initial condition data. This study examines efforts from the research and development of the Weather Forecast and Forecast (WRF) model of preliminary data using a satellite beam assimilation procedure for forecasting rainfall in the Ambon region for two different case studies in 2018. Six experimental models are carried out by assimilation of sensors AMSU-A and MHS satellites use the WRFDA 3DVar system. This research was conducted by increasing the assimilation analysis on the initial data model, analyzing the model skills in the dichotomy of rainfall predictions, rainfall criteria, spatial rainfall, and time series of rainfall accumulation compared to BMKG rainfall observation data. The results showed that the DA AMSU-A and MHS experiments correctly modified the initial condition data of the model. Meanwhile, the results of dichotomous verification revealed that the DA observation experiment had the highest skill score forecast compared to other assimilation. but more experiments are needed in the northern Sumatra area to provide more significant results.
\end{abstract}

Keywords: assimilation, WRFDA, satellite, Ambon

\begin{abstract}
Abstrak: Prediksi cuaca numerik saat ini terus dikembangkan untuk mengatasi kebutuhan akan ramalan curah hujan resolusi tinggi. Namun, ramalan cuaca numerik di Indonesia masih bermasalah dalam hal akurasi model numerik. Beberapa penelitian sebelumnya menunjukkan bahwa akurasi pemodelan sangat dipengaruhi oleh kesalahan dalam data kondisi awal. Penelitian ini mengkaji upayaupaya dari penelitian dan pengembangan model Prakiraan Cuaca dan Prakiraan (WRF) data awal menggunakan prosedur asimilasi pancaran satelit untuk prakiraan curah hujan di wilayah Ambon untuk dua studi kasus pada musim yang berbeda selama 2018. Enam model eksperimental dijalankan dengan asimilasi sensor satelit AMSU-A dan MHS menggunakan WRFDA sistem 3DVar. Penelitian ini dilakukan dengan analisis peningkatan asimilasi pada model data awal, analisis keterampilan model pada dikotomi prediksi curah hujan, kriteria curah hujan, curah hujan spasial, dan time series akumulasi hujan dibandingkan dengan data pengamatan curah hujan BMKG. Hasil penelitian menunjukkan bahwa eksperimen DA AMSU-A dan MHS memodifikasi data kondisi awal model dengan benar. Sementara itu, hasil verifikasi dikotomis mengungkapkan bahwa eksperimen DA observasi memiliki skor ketrampilan prakiraan tertinggi dibandingkan dengan asimilasi lainnya.
\end{abstract}


namun diperlukan lagi percobaan di daerah Sumatra utara untuk memberikan hasil yang lebih signifikan.

Kata kunci: asimilasi, WRFDA, satelit, Ambon

\section{PENDAhULUAN}

\subsection{Latar belakang}

Dewasa ini prakiraan hujan yang akurat memainkan peranan penting dalam berbagai bidang. Prakiraan hujan yang akurat akan membantu berbagai sektor seperti transportasi, penangkapan ikan, dan sektor penting lainnya. Informasi prakiraan cuaca juga sangat penting dalam peringatan bencana dini seperti banjir dan longsor yang dapat menimbulkan kerugian yang bersifat materil maupun immaterial. Metode prakiraan cuaca saat ini sudah sangat berkembang, metode prakiraan cuaca numerik dapat digunakan oleh prakirawan cuaca yang memudahkan prakirawan cuaca dalam memprediksi cuaca kedepan. Namun prediksi prakiraan cuaca numerik terkadang memiliki hasil prakiraan yang kurang tepat. Skill prediksi cuaca operasional BMKG hanya baik pada prediksi dikotomi hujan atau tidak hujan saja, sedangkan untuk prediksi hujan lebat dan sangat lebat masih memiliki skill yang sangat rendah (Gustari dkk., 2012). Oleh karena itu diperlukannya lagi pengembangan dalam prakiraan cuaca numerik yang dapat meningkatkan kemampuan dalam prediksi cuaca yang akurat. perbaikan kemampuan prediksi cuaca numerik dapat dilakukan dengan mengasimilasikan data inisial model cuaca dengan data observasi.

\subsection{Weather Research Forecaster (WRF)}

Weather Research and Forecasting (WRF) merupakan salah satu sistem prakiraan cuaca numerik yang didesain untuk penelitian dan kebutuhan operasional prakiraan cuaca. WRF merupakan hasil kerjasama berbagai lembaga antara lain National Center for Atmospheric Research (NCAR), the National Centers for Enviromental Prediction (NCEP), Forecast System Laboratory (FSL), Air Force Weather Agency (AFWA), Naval Research Laboratory, Universitas Oklahoma dan Federation Aviation Administration (FAA). WRF memungkinkan peneliti untuk menghasilkan simulasi atmosfer berdasarkan data observasi (Skamarock et al. 2008). WRF juga merupakan aplikasi open source yang dapat digunakan dan dikembangkan oleh peneliti secara bebas. Untuk medapatkan hasil prediksi curah hujan yang lebih akurat dapat dilakukan dengan konfigurasi skema fisik yang tersedia maupun juga dengan perbaikan asimilasi data inisial. 


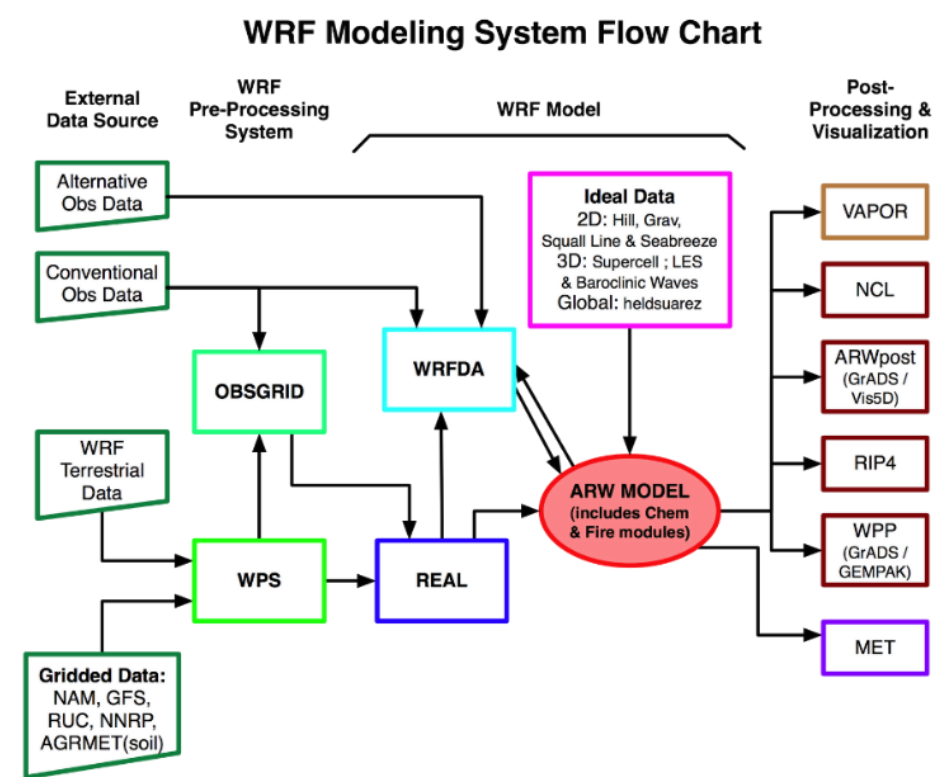

Gambar 1. alur kerja model numerik WRF (Wang et al. 2016)

\subsection{Asimilasi Data}

Asimilasi data merupakan suatu metode estimasi yang diperoleh dari penggabungan antara output model prakiraan cuaca numerik dan data-data pengukuran. Dalam beberapa tahun terakhir, model mesoscale resolusi tinggi diinisialisasi dengan menggunakan teknik data asimilasi (3DVar / 4DVar) yang diterapkan untuk mempelajari fenomena meteorologi (Kalnay, 2003). Dalam penelitian kali ini asimilasi dilakukan dengan merubah initial condition (kondisi awal) model cuaca Global Forecast System yang berosolusi $0.25^{\circ} \mathrm{x} 0.25^{\circ}$ dengan data radiasi oleh sensor satelit AMSUA dan sensor satelit MHS serta juga asimilasi dengan menggunakan data observasi permukaan yang dikumpulkan secara operasional oleh National Centeres for Envirovmental Prediction (NCEP) data observasi meliputi permukaan darat maupun lautan. Penilitian kali ini juga menggunakan Teknik 3DVar melalui WRFDA (WRF-Data Asimilation) sebagai aplikasi asimilasi data. Adapun persamaan yang digunakan dalam Teknik 3Dvar Adalah (kalnay 2003):

$J(x)=J_{b}+J_{0}$

$J(x)=\frac{1}{2}\left[y^{0}-H(x)\right]^{T} R^{-1}\left[y^{0}-H(x)\right]+\left[x-x^{b}\right]^{T} B^{-1}\left[x-x^{b}\right]$.

$2 J(x)=\left[y^{0}-H(x)\right]^{T} R^{-1}\left[y^{0}-H(x)\right]+\left[x-x^{b}\right]^{T} B^{-1}\left[x-x^{b}\right]$

$y^{b}-H(x)=x^{b}\left[\left[x-x^{b}\right]\right]=\left[y^{0}-H(x)^{b}\right]-H\left[x-x^{b}\right]$.

Persaamaan 3 dimasukan ke persamaan 4 maka menghasilkan:

$2 J(x)=\left[\left[y^{0}-H\left(x^{b}\right)\right]-H\left[x-x^{b}\right]\right] R^{-1}\left[\left[y^{0}-H\left(x^{b}\right)\right]-H\left[x-x^{b}\right]\right]+\left[x-x^{b}\right]^{T} B^{-1}\left[x-x^{b}\right]$

$2 J(x)=-\left[y^{0}-H\left(x^{b}\right)\right]^{T} R^{-1} H\left[x-x^{b}\right]-\left[x-x^{b}\right]^{T} H^{T} R^{-1}\left[y^{0}-H\left(x^{b}\right)\right]$

$+\left[y^{0}-H\left(x^{b}\right)\right]^{T} R^{-1}\left[y^{0}-H\left(x^{b}\right)\right]+\left[x-x^{b}\right]^{T} H^{T} R^{-1} H\left[x-x^{b}\right]+\left[x-x^{b}\right]^{T} B^{-1}[x-$

$\left.x^{b}\right]$........(6) Persamaan 6 diturunkan terhadap $\left[x-x^{b}\right]$ menghasilkan:

$\nabla J(x)=-0-H^{T} R^{-1}\left[y^{0}-H\left(x^{b}\right)\right]+0+H^{T} R^{-1}\left[x-x^{b}\right]+B^{-1}\left[x-x^{b}\right]$

Meminimalisir selisih estimasi model dan observasi maka nilai $\nabla J(x)$ dimisalkan menjadi 0 :

$0=\left[x-x^{b}\right]\left[B^{-1}+R^{-1} H^{T} H\right]-H^{T} R^{-1}\left[y^{0}-H\left(x^{b}\right)\right]$. 


\section{DATA DAN METODE}

\subsection{Lokasi Penelitian}

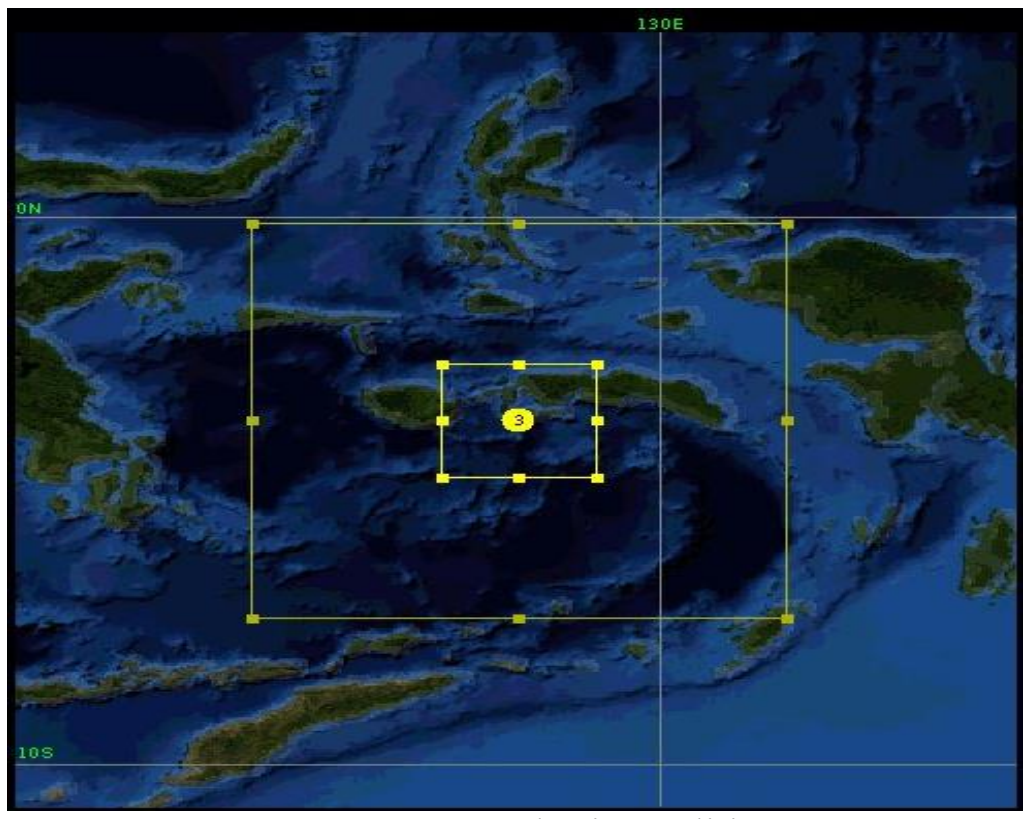

Gambar 2.1. Lokasi Penelitian

Lokasi penelitian yang dipilih adalah Pulau Ambon. Letak Kota Ambon sebagian besar berada dalam wilayah Pulau Ambon, yang secara geografis berada pada posisi: $3^{\circ}-4^{\circ}$ Lintang Selatan dan $128^{\circ}-129^{\circ}$ Bujur Timur, di mana secara umum Kota Ambon meliputi wilayah di sepanjang pesisir dalam Teluk Ambon dan pesisir luar Jazirah Leitimur dengan total panjang garis pantai 102,7 Km. Sesuai Peraturan Pemerintah Nomor 13 Tahun 1979 luas wilayah Kota Ambon seluruhnya seluas $377 \mathrm{~km} 2$ dan berdasarkan hasil survey tata guna tanah tahun 1980 luas wilayah daratan Kota Ambon tercatat seluas 359,45 Km2.

\subsection{Data}

Pada penelitian kali ini menggunakan model cuaca yang telah diasimilasi maupun yang belum diasimilasi sebagai pemnbanding serta menggunakan data pengamatan curah hujan daerah Jakarta dan medan sebagai data kondisi kenyataannya. Adapun data yang digunaka sebagai berikut :

1. untuk model cuaca digunakan data Global Forecast System (GFS) yang dikeluarkan oleh

National Centers for Environmental Prediction (NCEP) resolusi $0.25^{\circ} \times 0.25^{\circ}$ dengan periode 24 - 25 Juli 2013 untuk studi kasus daerah Ambon diunduh melalui website (http://nomads.ncdc.noaa.gov/). Model GFS yang digunakan mempunyai waktu inisial (cycle) 00,06,12,18,24 UTC. Kemampuan prediksi global dari NCEP ini telah meningkat secara signifikan dalam dua dekade terakhir, meskipun kualitasnya di daerah tropis kurang baik akibat sedikitnya pengamatan (Kalnay, 2003).

2. untuk asimilasi model digunakan data radiasi dari sensor satelit AMSU-A (Advanced Microwave Sounding Unit-A) dan MHS (Microwave Humidty Sensor) untuk memperbaiki nilai parameter suhu model yang dapat diunduh melalui website 
https://rda.ucar.edu/ dengan kode dataset ds735.0, data yang diambil memiliki waktu yang sama dengan waktu inisial awal model yaitu pada 24 Juli 2013 pukul 00.00 UTC.

3. untuk data kondisi real saat waktu penelitian digunakan data pengamatan observasi parameter cuaca tekanan,suhu,kelembaban,dan curah hujan dari stasiun meteorologi Pattimura, Ambon.

Data-data tesbut diolah menggunakan komputer dengan spesifikasi prosesor intel core i7 dan perangkat lunak WRF 3.9.1 serta perangkat lunak The Grid Analysis and Display System (GrADS) untuk memvisualisasikan hasil dalam grafik dan data secara spasial.Dalam pengerjaannnya di dalam model WRF-ARW hanya digunakan 1 domain yang meliputi wilayah Indonesia dengan resolusi $30 \mathrm{~km}$. Opsi fisis dalam penelitian ini menggunakan model WRF-ARW skema default yaitu opsi fisis standar tanpa mengubah opsi fisis dalam model. Adapun konfigurasi opsi fisis yang digunakan dalam penelitian dapat dilihat dalam tabel sebagai berikut:

Tabel 2.1. Konfigurasi Opsi Fisis Model WRF-ARW

\begin{tabular}{||l||l||}
\hline \hline Opsi Fisis & Domain 1 \\
\hline \hline Model WRF-ARW & (DO1) \\
\hline \hline Resolusi & 27 Km \\
\hline \hline Longwave Radiation & Rapid Radiative Transfer Model \\
\hline \hline Shortwave Radiation & Dudhia Scheme \\
\hline \hline Surface Layer & Noah Land Surface Model \\
\hline \hline Planetary Boundary Layer & YSU-Scheme \\
\hline \hline Microphysics & Lin et al scheme \\
\hline \hline Cumulus Parameterization & Grell F.E \\
\hline
\end{tabular}

\subsection{Metode}

Hasil dari pengolahan model asimilasi dan non asimilasi diverifikasi menggunakan metode root mean squre (RMSE) pada parameter cuaca untuk mengukur seberapa besar perubahan galat model setelah dilakukan asimilasi terhadap sebelum dilakukan asimilasi dan melihat korelasinya. 


\section{ANALISA DAN PEMBAHASAN}

Hasil keluaran (output) dari WRFDA-3DVar adalah perbaikan data input untuk model WRF. Dalam bagian ini, akan ditampilkan hasil dari prediksi non asimilasi dan asimilasi yang kemudian akan dibandingkan dengan data dukung lain berupa data observasi permukaan stasiun. Adapun parameter yang akan digunakan dalam penelitian ini adalah suhu permukaan,suhu titik embun, kelembaban udara dan tekanan udara permukaan serta hujan di wilayah Stasiun Meteorologi Penerbangan Pattimura (128.089 BT dan 3.707 LS).

\subsection{Suhu Udara Permukaan}

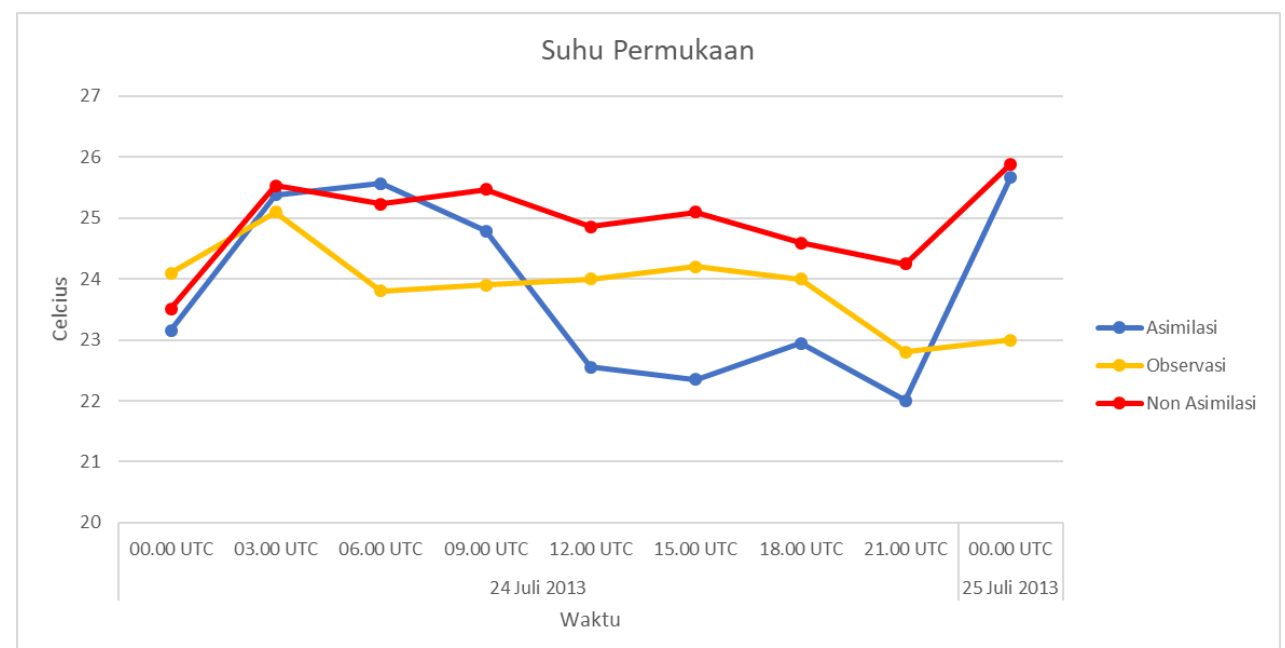

Gambar 2. Grafik Perbandingan Suhu Udara dari data observasi dan WRF (non Asimilasi dan Asimilasi) 24 - 25 Juli 2013 di Stasiun Meteorologi Pattimura Ambon

Berdasarkan Gambar 2 menunjukan grafik perbandingan suhu udara hasil keluaran WRFARW sebelum asimilasi dan sesudah asimilasi terhadap data hasil observasi dari Stasiun Meteorologi patimura ambon pada tanggal 24 Juli 2013, suhu udara hasil observasi memperlihatkan adanya kenaikan suhu udara mulai pagi hari hingga siang hari (jam 00.00 UTC- 03.00 UTC) dan mencapai nilai maksimum pada jam 03.00 UTC sebesar $25.1{ }^{\circ} \mathrm{C}$. Dan grafik nilai suhu bergerak turun hingga tanggal 24 Juli 2013 jam 21.00 UTC. Sedangkan pada grafik suhu udara hasil keluaran model WRF baik sebelum asimilasi maupun tidak, samasama terjadi kenaikan suhu udara dari jam 00.00 UTC, namun mencapai suhu udara maksimum pada jam 03.00 UTC dan menurun kembali hingga jam 21.00 UTC. Secara umum, hasil keluaran model WRF sebelum diasimilasi overestimated dan setelah diasimilasi cenderung underestimated, namun secara subyektif grafik hasil keluaran model dan hasil observasi menunjukkan pola fluktuasi yang hampir sama. 


\subsection{Kelembaban}

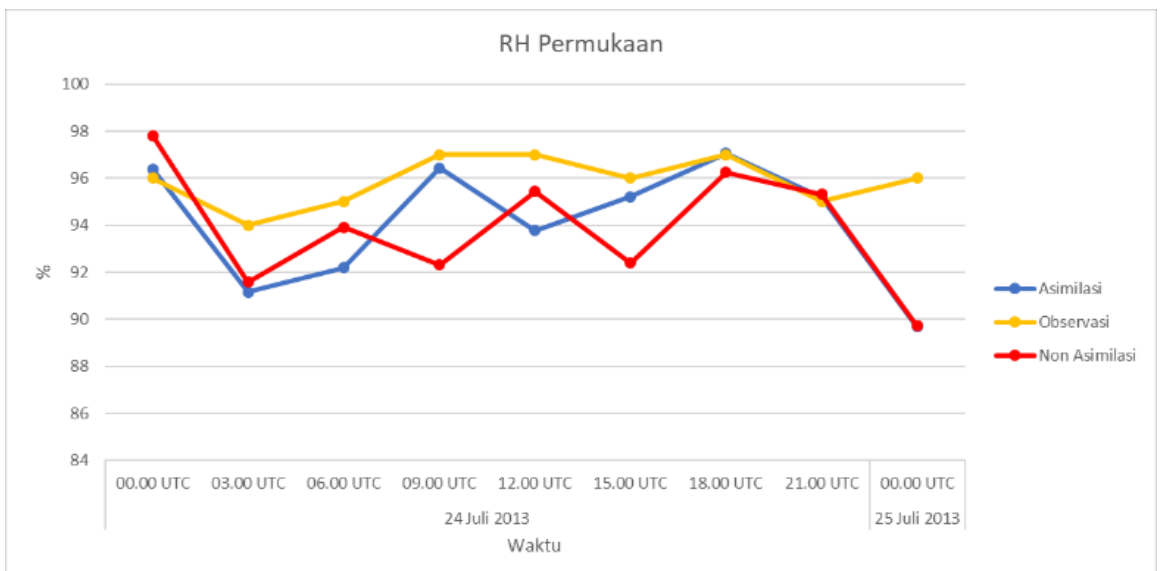

Gambar 2. Grafik Perbandingan Kelambaban dari data observasi dan WRF (non Asimilasi dan Asimilasi) 24 - 25 Juli 2013 di Stasiun Meteorologi Pattimura Ambon

Dari grafik kelembaban udara hasil keluaran model WRF sebelum diasimilasi dan setelah diasimilasi terhadap data hasil observasi dari Stasiun Meteorologi Pattimura Ambon pada tanggal 24 Januari 2015, pada grafik kelembaban udara hasil observasi terlihat bahwa terjadi penurunan kelembaban udara dari jam 00.00 UTC hingga mencapai kelembaban udara minimum pada jam 03.00 UTC yaitu sekitar 94\% dan meningkat kembali hingga jam 18.00 UTC. Sedangkan pada grafik kelembaban udara hasil keluaran model WRF baik sebelum asimilasi maupun tidak, sama-sama terjadi penurunan kelembaban udara yang berfluktuasi dari jam 00.00 UTC, namun mencapai kelembaban minimum untuk non asimiliasi pada jam 00.00 tanggal 25 Juli UTC yaitu sebesar 90\% dan kelembaban minimum untuk asimilasi pada jam 00.00 tanggal 25 UTC sebesar 90\% . Ini berarti bahwa kelembaban udara minimum hasil Secara umum, hasil keluaran model WRF-ARW sebelum diasimilasi dan setelah diasimilasi cenderung underestimated, namun secara subyektif grafik hasil keluaran model dan hasil observasi menunjukkan pola fluktuasi yang hampir sama.

\subsection{Tekanan udara permukaan}

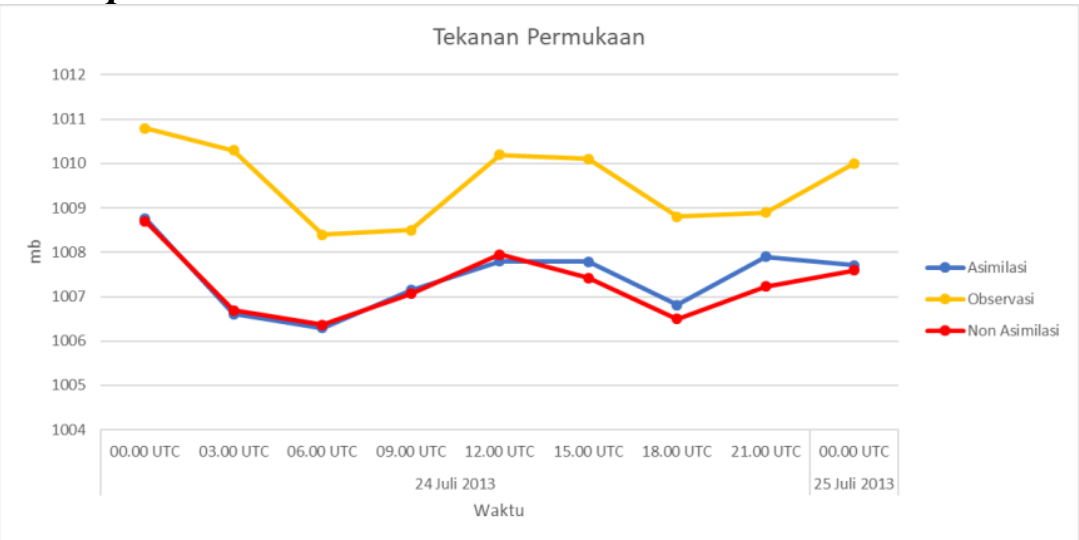

Gambar 3. Grafik Perbandingan tekanan udara permukaan dari data observasi dan WRF (non Asimilasi dan Asimilasi) 24 - 25 Juli 2013 di Stasiun Meteorologi Pattimura Ambon 
Dari grafik tekanan udara hasil keluaran model WRF-ARW sebelum diasimilasi dan setelah diasimilasi terhadap data hasil observasi dari Stasiun Meteorologi Maritim Perak pada tanggal 24 Juli 2015, pada grafik tekanan udara hasil observasi terlihat bahwa tekanan udara maksimum terjadi pada jam 00.00 UTC dan tekanan udara minimum terjadi pada jam 06.00 tanggal 24 Juli 2015 UTC. Sedangkan pada grafik tekanan udara hasil keluaran model WRF baik sebelum asimilasi maupun tidak, tekanan udara maksimum terjadi pada 00.00 UTC dan tekanan udara minimum terjadi pada jam 06.00 UTC. Dan untuk perbandingan tekanan udara permukaan model WRF hasil asimilasi dan non-asimilasi menunjukan pola yang hampir sama serta nilai tekanan udara yang tidak terdapat perbedaan yang mencolok. Secara umum, hasil keluaran model WRF sebelum diasimilasi dan setelah diasimilasi cenderung underestimated terhadap observasi.

\subsection{Hujan}

Berikut merupakan peta distribusi spasial intensitas hujan hasil output WRF
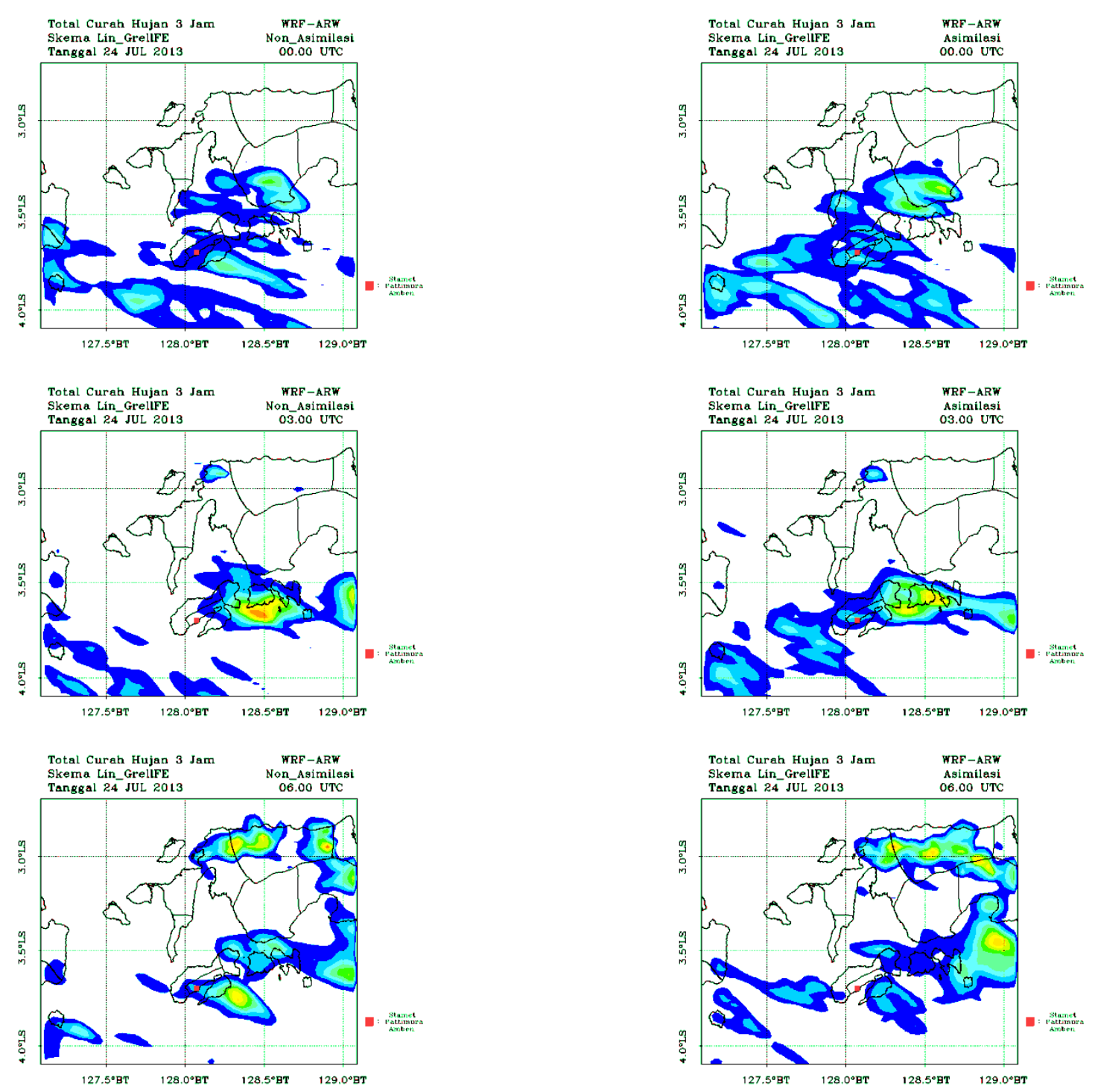

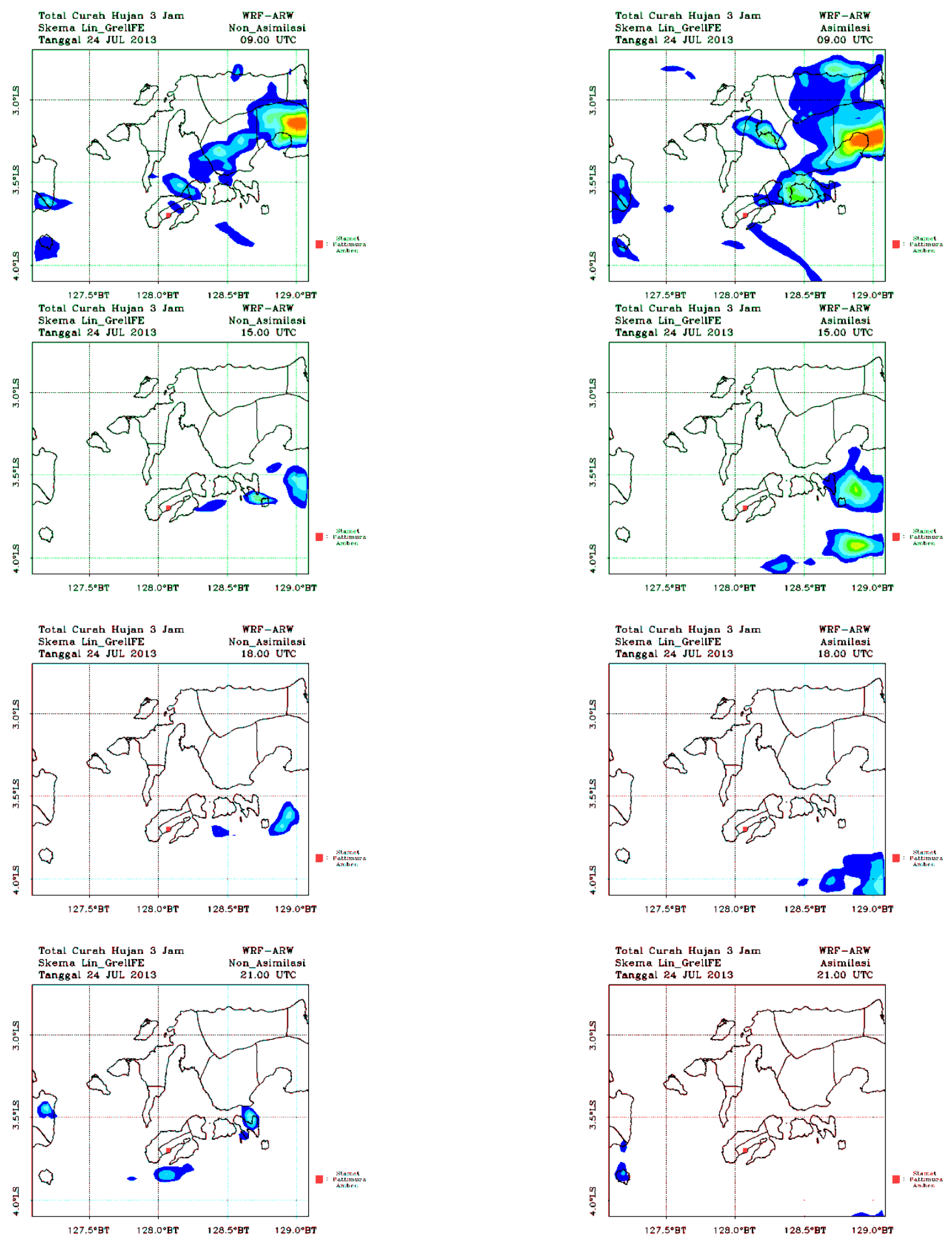

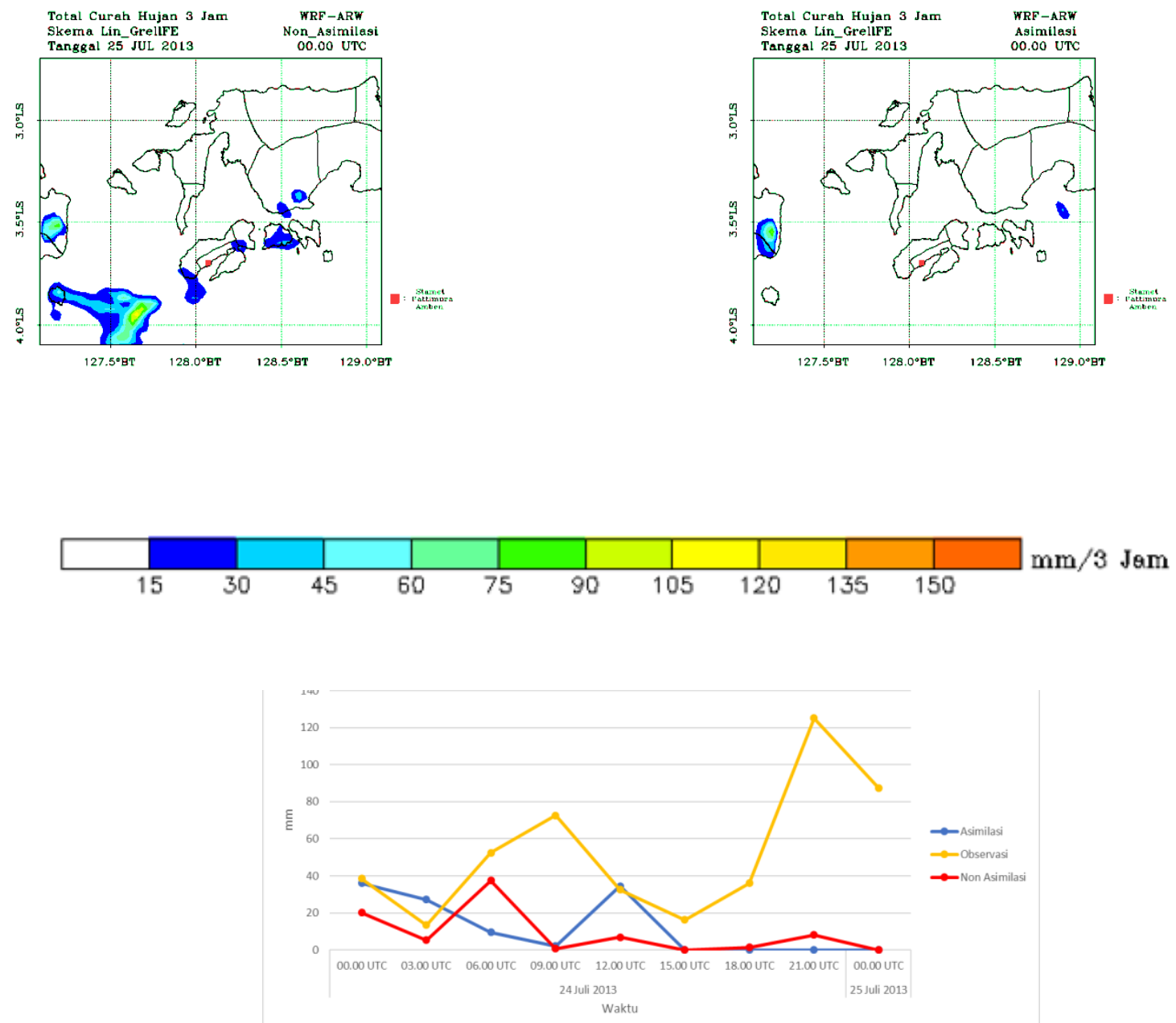

Gambar 4. Grafik Perbandingan tekanan udara permukaan dari data observasi dan WRF (non Asimilasi dan Asimilasi) 24 - 25 Juli 2013 di Stasiun Meteorologi Pattimura Ambon

Dari gambar 4, terlihat bahwa curah hujan hasil asimilasi dan tanpa asimilasi cenderung lebih rendah dibandingkan dengan data observasinya. namun hasil dari asimilasi memiliki kecocokan hampir sama nilai curah hujan dengan observasi pada jam 12.00 UTC pada tanggal 24 Juli 2013 dengan nilai curah hujan hasil asimilasi $34.4 \mathrm{~mm}$ dan observasi $32.5 \mathrm{~mm}$. 


\subsection{Verifikasi Hasil}

Tabel 3.1 Hasil Verifikasi antara hasil WRF (asimilasi) dengan observasi

\begin{tabular}{|c|c|c|c|c|}
\hline \multirow[b]{2}{*}{ Parameter } & \multicolumn{2}{|c|}{ Korelasi } & \multicolumn{2}{|l|}{ RMSE } \\
\hline & $\begin{array}{c}\text { Non } \\
\text { Asimilasi }\end{array}$ & Asimilasi & $\begin{array}{c}\text { Non } \\
\text { Asimilasi }\end{array}$ & Asimilasi \\
\hline Suhu udara & 0.079 & 0.154 & 1.389 & 1.464 \\
\hline Curah hujan & -0.018 & -0.486 & 56.934 & 59.49 \\
\hline $\begin{array}{l}\text { Kelembaban } \\
\text { udara }\end{array}$ & -0.524 & 0.536 & 3.124 & 2.737 \\
\hline Tekanan udara & 0.725 & 0.608 & 2.352 & 2.245 \\
\hline
\end{tabular}

Dari tabel korelasi antara hasil keluaran model WRF hasil asimilasi dengan hasil observasi, terlihat bahwa korelasi dari parameter suhu udara, suhu titik embun, dan kelembaban relatif menunjukkan korelasi yang cukup membaik dibandingkan dengan sebelum diasimilasi. Untuk parameter suhu udara, korelasi antara hasil model WRF sebelum diasimilasi dan setelah diasimilasi terhadap observasinya masing-masing bernilai 0.079 dan 0.154 . Sementara untuk parameter curah hujan, korelasi antara hasil model WRF sebelum diasimilasi dan setelah diasimilasi terhadap observasinya masing-masing bernilai -0.018 dan -0.486 . Untuk parameter Kelembaban udara korelasi antara hasil model WRF-ARW sebelum diasimilasi dan setelah diasimilasi terhadap observasinya masing-masing bernilai -0.524 dan 0.536. Sedangkan untuk parameter tekanan udara, korelasi antara hasil model WRF-ARW sebelum diasimilasi dan setelah diasimilasi terhadap observasinya masing-masing bernilai 0.725 dan 0.608 . Secara umum, korelasi antara hasil keluaran model WRF-ARW setelah diasimilasi dengan hasil observasi lebih besar daripada sebelum diasimilasi.

\section{KESIMPULAN}

Model cuaca merupakan representasi yang lebih sederhana dari cuaca yang sesungguhnya, dalam bentuk persamaan-persamaan matematis dari fisika dan dinamika yang saling berhubungan, yang merepresentasikan proses-proses di dalam atmosfer. Rangkaian persamaan ini biasanya diselesaikan dengan bantuan komputer. Dari hasil simulasi menggunakan model cuaca Weather Reseacrh and Forecasting (WRF) pada domain daerah Ambon dan sekitarnya menunjukkan hasil yang cukup memuaskan. Hasil dari keluaran WRF dapat merepresentasikan dengan baik beberapa parameter meteorologi seperti kelembaban udara, curah hujan dan tekanan udara. Namun, untuk parameter suhu hasilnya kurang merepresentasikan dengan hasil observasi. Pulau Ambon dan sekitarnya merupakan daerah pantai yang kondisi cuacanya sangat dipengaruhi oleh sirkulasi angina darat dan angina laut. Sehingga angin darat dan angin laut akan mendominasi perubahan cuaca daerah Pulau Ambon dan sekitarnya. 


\section{DAFTAR PUSTAKA}

Gustari, I., Hadi, T. W. , dan Hadi, S., Renggono, F., (2012), Akurasi Prediksi Curah Hujan Harian Operasional di Jabodetabek: Perbandingan dengan Model WRF. Jurnal Meteorologi dan Geofisika, vol.13, no.2, 119-130.

Junnaedhi, I.D.(2008). Pengaruh Asimilasi Data dengan Metode 3DVAR Terhadap Hasil Prediksi Cuaca Numerik di Indonesia. Bandung: Meteorologi ITB.

Kalnay, E. (2003). Atmospheric Modelling, Data Assimilation and Predictability. Cambridge, UK: Cambridge University Press.

Skamarock, W.C., Klemp, J.B., Dudhia, J., Grill, D. O., Barker, M. D., Duda, M. G., Huang X.Y., Wang W., Powers J.G., (2008). A Description of the Advanced Research WRF Version 3, Mesoscale and Microscale Meteorology, National Center for Atmospheric Research, NCAR Technical Note, NCAR/TN-475+STR, Colorado. 